\title{
Participatory Budgeting in the Major Cities in Poland - Case Study of 2018 Editions
}

\author{
MAŁGORZATA MADEJ
}

\section{Sciendo}

Politics in Central Europe (ISSN: 1801-3422)

Vol. 15, No. 2

DOI: 10.2478/pce-2019-0017

\begin{abstract}
The paper refers to the social innovation of participatory budgeting which has become a very popular tool for stimulating citizen participation at the local level in Poland. It focuses on the major cities, defined as capitals of the voivodeships or regions. Based on the data concerning 2018 participatory budgeting editions in the eighteen cities, it describes the funding, organisation of the process, forms of voting and voter participation as well as the nature of projects selected and implemented. According to the amended Act on the Local Self-Government, organisation of participatory budgeting will only be obligatory for Polish cities from 2019. Despite that fact, it has already become quite popular and broadly applied in local communities. However, citizens' participation and involvement in the process seems quite low, suggesting a need for experience sharing and improvement of the initiative. Also, project selection reflects the influence of various social groups within urban communities, rather than assisting groups which are at risk of marginalisation.
\end{abstract}

Keywords: participatory budgeting, urban governance, local self-government, Poland

Local government is treated as an important value, a major instrument of decentralisation in modern Europe and a tool of improvement in the quality and efficiency of governance. However, it is also defined to serve citizens' participation. For example, the European Charter of Local Self-Government highlights that the principle of freely elected local authorities 'shall in no way affect recourse to assemblies of citizens, referendums or any other form of direct citizen participation where it is permitted by statute' (European Charter 1985). This puts 
local government in the context of stimulating residents to take responsibility for their neighbourhoods. As Tsobanoglou and Harms argue, participation is necessary to address the modern crisis of distrust in politics, quoting various mechanisms applied within the local democracy (Tsobanoglou - Harms 2018). Participatory budgeting is one of the tools which may achieve the objective of citizen mobilisation, although it cannot be considered separate from other means of stimulating citizen activity.

In the last decade, participatory budgeting has become highly popular in Poland, even without legal provisions binding local authorities to implement such measures in their governance processes (Rytel-Warzocha 2018: 392). It's been applied in a growing number of local government units, mainly the communes, but also in six voivodeships, on the regional level.

\section{Participatory budgeting - concept and its developments}

Participatory budgeting (PB) is a very broadly studied concept of involving citizens in local or sublocal governance through their inclusion in financial decision-making processes. In its original shape, established in Porto Alegre, Brazil in the 1980s, it was a response to inequality in access to power in the city (de Olivero Dutra 2014: 11). It was perceived as an important social innovation and chance to improve quality of governance due to better and better informed decisions (Brun-Martos - Lapsley 2017: 1008), to encourage local communities to express their needs, as well as to take responsibility for their environment, and as a tool of increasing transparency and civil control in governing (Hartog - Bakker 2018). With these benefits in view, self-governments all over the world strived to implement this solution, but it should be stressed that $\mathrm{PB}$ is always a component of a broader system of participative governance (Avritzer 2017: 47), and only thus it may serve to improve the level of trust and legitimacy on the local level (Swaner 2017). Thus, it becomes incorporated in a set of traditions, principles and arrangements in place developed by the local community and defined by its authorities, this is why the general name of 'participatory budgeting' encompasses a great variety of solutions in different parts of the world. Undoubtedly, 'while the diffusion of PB is impressive, there are complications: PB is being implemented in very different ways, largely as a result of legal, social, political and historical traditions that exist in different countries' (Brun-Martos - Lapsley 2017: 1007). Thence, the importance of analysing participatory budgeting in various geographical, legal and historical contexts to verify how the basic concept of delegating the power to decide on a part of local authorities' expanses to the entire community is applied in different circumstances and what goals it can achieve.

Participatory budgeting is frequently associated with such concepts as decentralisation, governance and participation and it needs to be highlighted 
that these are frequently perceived and defined as values involved in the human right to good administration (Charter 2000: 41). Decentralisation, which has been a subject of very broad research, can be defined as 'a distribution of competencies which allows their significant part to be transferred from the central government to lower echelons of power' (Chrzanowski - Sobczak 2017: 14). A well-designed decentralisation is considered to bring benefits to the communities, as it is 'widely advocated as a means to foster legitimacy, stimulate more equitable growth, enhance policy efficiency and increase democratic accountability; it is even made a key element of "good governance; in general" (Mueller 2015: xxii). Its advantages include better accommodation of social diversity and discrepancies of interests, more efficient management of public affairs, as well as greater stimulation of local activists, whose voice is better heard on the lower level of governance. Even though local and specialist self-government is the fundamental channel of decentralisation (Kmieciak 2016), currently more stress is put on the potential to decentralise competencies even further, to include smaller, even sub-local communities 'for the sake of efficiency or to promote civic participation' (Liebmann 2000: 169). In these terms participatory budgeting may serve as a way to stimulate the citizens' involvement and encourage them not only to participate in the processes provided by the authorities, but also to self-organise and to build small communities around specific problems affecting the particular neighbourhood.

In this way, participatory budgeting may also contribute to implementation of good governance principles on the sub-local, local and even regional levels. According to the classical definition by the World Bank, 'the manner in which power is exercised in the management of a country's economic and social resources for development' (International Fund for Agricultural Development, 1999). It includes a range of elements: participation, rule of law, transparency, responsiveness, orientation on consensus, equity and inclusiveness, effectiveness and efficiency and accountability. Other sources may offer slightly different listings, e.g. openness, partnership, effectiveness, efficiency, accountability or cohesion (Kobielska - Lisowska 2014). A well-designed participatory budgeting initiative may well affect all of them by introducing the local residents into the decision-making processes affecting their closest neighbourhoods. With the fundamental idea of encouraging direct participation of all citizens, participatory budgeting corresponds to the principles of participation, equity and inclusiveness, but it may also enhance accountability through greater transparency of the process, and above all, by increasing the residents' involvement and interest in the sublocal and local issues. Additional channels of communicating interests and preferences may also affect more efficient management of the local community's resources and the local space, thus making the local or sublocal communities more responsive to the changing opinions and expectations of the inhabitants. Importantly, such solutions may also benefit minority groups; 
firstly, by providing them with a possibility to participate in the political system in a less formalised way, and secondly, by making it easier to promote and implement their initiatives.

All of these objectives are directly associated with the level of social participation. On one hand, the efficiency of any participatory scheme is determined by the citizens or inhabitants' trust in it and their will to take in the process. On the other hand, a successful scheme may entice more activity within the community. In political science, this term is defined as 'a tool to engage citizens in the public life and a way to redistribute power to particular echelons' (Wójcicki 2013). Also perceived as a crucial element of civil society, it is frequently encouraged in democratic countries and to ensure inclusiveness with respect to interest of all citizens. Importantly, in the context of the classification referred to as the ladder of participation, participatory budgeting can be perceived as the highest level of co-deciding, more advanced than the other two - informing and consulting (Waligóra 2014).

\section{Political and social participation in Poland}

Political participation in Poland remains quite low, although, as shown in Table 1., in the 2018 local elections, voters in the largest cities and capitals were more committed to voting than in other types of municipalities. In most cities (16 out of 18 ) the voter turnout was higher than regionwide in the voivodeship the city is the capital of, however in 14 of them it ranged between 45 and $55 \%$, which is quite a high result in the Polish elections, but still only close to half of the residents. Also, on the lower level of local governance, the participation of citizens remains insufficient in terms of establishing efficient communication and involving communities in governance of their neighbourhoods. Especially in urban communes, popularity of sublocal self-government (osiedla, dzielnice) is very low, as measured by voter turnout at elections, as well as by the numbers of candidates for sublocal councils or number of initiatives brought by citizens themselves. This shows the unused potential of participation in the cities and the citizens' concern about their local communities. The cities strive to mobilise this potential by participatory budgeting, too.

The social and volunteer participation is stable, as an extensive study in 2013 showed that $18 \%$ of Poles were involved in formal groups or organisations, $27 \%$ worked for their closest community or neighbourhood and $9 \%$ participated in actions taken by churches or religious groups. The total number of persons getting involved in social action was $34 \%$, similar to values observed in earlier years (Zaangażowanie społeczne Polek i Polaków 2014). However, an increasing number of Polish citizens contribute financially to non-governmental organisations and charities, especially through the mechanism which allows them to assign $1 \%$ of their due yearly income tax to a selected organisation. Therefore, 
it should be assumed that the current evolution of Polish society may serve to enhance the level of social activism and participation, if relevant, creative and stimulating tools are provided.

The local authorities attempt to enhance citizens' participation by introducing various forms of participation, for instance civic panels in Gdansk (Official Portal of the Municipality of Gdansk, accessed 24-1-2019), local microgrants in Wrocław (Mikrogranty, accessed 11-3-2019), referenda to consult particular decisions (National Electoral Commission, accessed 11-3-2019) or other forms of public consultations (Waligóra 2014). Participatory budgeting, first introduced in Poland in 2011 in Sopot (Olejniczak - Bednarska-Olejniczak 2008), has grown more and more popular and by amendment of the Act on Local Government introduced in 2017, organisation of participatory budgeting is obligatory for all urban counties starting in 2019 (Act 1990).

\section{Local government in Poland}

Poland has a three-tier territorial self-government with 16 regions (województwo) on the regional level, counties (powiat) on the subregional level and communities (gmina) as the basic unit of local organisation and authorities. Each unit of self-government is defined as a community of citizens, thus indicating the local authorities' obligations concerning community building and stimulation of local activity and participation.

As a general rule, each county comprises several communities (Sześciło Kulesza 2012); however, with the average population per county of about 101 thousand, it would be impracticable to treat the largest metropolises like other municipalities. Thence, the specific status of 'urban counties' (powiat grodzki) (Act, 1998), which are communities with competencies and responsibilities of counties. In 2018, there were 66 communities of this status in Poland, including all 18 capital cities of voivodeships ${ }^{1}$ (Ministry of Internal Affairs and Administration, accessed 11-3-2019). After initial inconsistencies in interpretation, the 2001 amendment to the local government acts clarified that such cities are classified as communities, obliged to perform responsibilities assigned to poviats (Act 2001). According to the Polish Constitution, the local and regional administration (both self-government and deconcentrated administration) is organised by the principles of decentralisation and subsidiarity. The residual competencies in all local issues are assigned to the communal self-government, while the act on poviat government provides an exclusive list of responsibilities of this sub-regional echelon of administration (Act, 1990). Thus, municipalities acting as poviats are responsible for such areas as management of municipal roads, streets, bridges and squares; provision of water and sewage services; provision

1 In two voivodeships - Kujawsko-Pomorskie and Lubusz - two cities share the capital status. 
of waste disposal; provision of electricity and gas; public transportation; health care; public education; organisation of cultural activities as communities, but also for issues related to disaster management, public security and other areas assigned to poviats (Act 1998). In the case of urban poviats these responsibilities are combined.

As mentioned above, there are 18 regional 'capital cities' of voivodeships in Poland. They differ in size, level of economic development and wealth (Table 2), as well as in social and political traditions. Like the regions themselves (Skrzypiński 2017), the capital cities have their specific features and problems, depending on their history, traditions, location, level and character of their economic development, as well as the local community, its education, diversity, attitudes and involvement. The discrepancies and different challenges they face require individual policies and selection of tools. However, encouraging participation is perceived everywhere as a value and an opportunity, thence the popularity of participation-promoting methods applied in Polish metropolises.

\section{Comparison of participatory budgeting in voivodeship capitals}

\section{Material and methods}

The following section analyses the participatory budgeting in 18 voivodeship capitals in Poland. The objective of the study was to verify the cities' actual commitment to implementation of participatory budgeting, evidenced by the funding assigned for participatory budgeting; to assess the social outcome in terms of the participation in the broadest (and easiest) stage of the process, i.e. the consultation vote; and to check the final impact of the initiative on the cities by way of a short overview of the projects selected and implemented. To gain a deeper understanding of the process, its organisation was described, too, considering the classification of submissions applied by the cities' authorities in the vote.

All of the analysed cities had implemented this initiative, so for comparative purposes a single edition was selected: the 2018 edition. All of the data were acquired from dedicated websites of participatory budgeting at the respective Municipal Offices or else by direct enquiries to municipal officials responsible for participatory budgeting.

\section{Funds assigned to participatory budgets}

The amounts assigned to participatory budgeting processes in the analysed cities varied strongly, depending on the size and economic status of the city. They ranged from 2,500,000 PLN to 64,000,000 PLN (Table 3), which means that the largest participatory budget (in the capital and the wealthiest city in Poland - 
Warsaw) was over 25 times higher than the lowest one in Opole. However, if the numbers are analysed as a percentage of the municipal budget instead as absolute values, the sequence is different. The highest percentage (almost 1\% of total municipal expenses) is noted in two cases (Łódź and Katowice), and the lowest one is 0, 22\% (again in Opole).; however, the difference is much less than in the case of absolute numbers (in this case it is only fivefold), because quite naturally larger cities with higher budgets are able to allocate higher amounts to participatory projects. However, the percentages are more suggestive of a rule: none of the analysed 18 cities assigned more than $1 \%$ of their overall budgetary expenses to the citizens' participatory process. Even though the sheer concept of participatory budgeting and the process is attractive and stimulating for citizens, the low level of funding may discourage participation in the longer term.

The municipal participatory budgets vary significantly in the number of projects selected for implementation (Table 4). Although it seems logical that the largest city with the largest participatory budget should fund the largest number of projects (especially if it is considered a combination of 18 separate participatory budgets in quarters of the city), but still the number results in the lowest average value per project. Only in two cities (Poznań and Szczecin) did the average value exceed 600,000 PLN, and in a further two (Wrocław and Kielce) was it above 400,000 PLN. The higher amounts may allow for funding of more difficult, larger-scale projects; however, the participatory budgeting process is addressed to lowest-level sublocal activists, so lower amounts may actually be useful in the case of smaller projects, especially soft projects, while even hard investment projects included in participatory budgeting are usually on a much lesser scale.

In analysing the average value of a project, it should also be considered that, as suggested by ngos specialising in urban participation (Kębłowski 2014: 23), all cities provided for different categories of projects to be funded (Table 5). Fifteen out of the 18 analysed cities applied a geographic division, with a certain amount assigned to projects concerning the entire city and a certain amount for projects on a sub-local level: quarters or neighbourhoods, depending on the organisation of sublocal units, or else special districts developed for the purpose of participatory budgeting. In such cases on the municipal level fewer projects were funded and their average value was higher, thus allowing for bigger-scale initiatives, provided that they benefited larger groups of inhabitants. In the sublocal category, it was possible to submit - and gain funding for - projects worth several thousand PLN (1,500-2,000 €). Some cities also added value-related categories (e.g. allocation of set amounts for big and small projects, in one case also microprojects) or else categories based on the character of the projects (soft vs. investment projects). In two cases, there were also 'specialist', participatory 'sub-budgets', assigned for specific types of projects: 
educational ones in Gorzów Wielkopolski and the renovation of historic buildings in Wrocław. Such diversification may be helpful for all parties involved: projects are easier to classify and supervise for the municipal administration, the vote is more clear for inhabitants, but this solution also facilitates development of applications by providing more clear frameworks for initiators of such submissions. Finally, it increases a sense of fairness among all parties, as any competition between large, municipal-scale projects and sublocal initiatives capable of drawing much smaller attention and addressed to smaller groups of beneficiaries could be impossible. Thus, municipal authorities attempt to encourage more diverse initiatives.

Importantly, division of the budget between various districts or quarters also serves to ensure that funding goes to different parts of the city and not only to the city-centre or most gentrified areas. Activation of local inhabitants is especially important in peripheral or sub-urban areas for several reasons. Firstly, frequent investment in those parts is more needed to keep inhabitants from commuting to the city centre for their daily errands and, secondly, social activity is usually focused in several areas and encouragement of even more citizen initiative in various parts of the city may contribute to more sustainable and equitable urban development.

\section{Citizens' participation in participatory budgeting votes}

Participatory budgeting is a long-term process with annual cycles with consultations, submission of projects, their formal verification and sometimes amendments, citizens' vote to select projects and, finally, the implementation of the selected ones (Demediuk - Solli - Adolfsson 2012). However, even the final stage of actually engaging public funding citizen-initiated and citizen-picked projects is not so spectacular and popular as the citizens' vote (Table 6). Since the participatory budgeting is designed to encourage citizen activity, the local authorities attempt to organise the vote in the most citizen-friendly form. All eighteen analysed cities provided for the possibility to vote online, and fourteen also distributed printed ballots to ensure that inhabitants who can't or don't want to participate in an internet vote are also invited to take part in the project selection. Out of the four cities which didn't, one organised additional counselling or assistance from municipal clerks for citizens for whom the virtual form could be too difficult, in two cases citizens were also allowed to vote in person at special meetings in Gorzów Wielkopolski or by coming to the Municipal Office (Katowice).

The analysis of voter turnout in the vote does not show any significant trend considering either the forms of vote or population of the city. Even though in bigger cities participatory budgeting could mobilise more voters, it still remained quite a low percentage of the formal population of registered 
inhabitants of the cities (since there are no uniform statistics concerning this group for various cities, the unregistered inhabitants are not considered, even though some cities allow all residents to vote in the participatory budgeting, regardless of their formal status). The range - both in the absolute numbers and percentage - is very broad, too: from fewer than 10,000 voters to almost 100,000 and from less than $5 \%$ of the population to almost one in four inhabitants, significantly lower than in the national elections. Still, the numbers are quite low, considering the potential of direct democracy and participation involved in participatory budgeting. It seems that the promotion of this is not yet sufficient or that the course and effects of the process are disappointing for the citizens. However, it should be highlighted that the promotion should rely primarily on bottom-up processes, inviting sublocal activists to face problems on the lowest level of the municipal administration, while activities by the local authorities, as well as the municipal offices should rather provide a framework and support the action addressed directly to inhabitants concerned with particular projects and initiatives.

\section{Projects implemented through the mechanism of participatory budgeting}

Considering the diversity of the cities on various levels - differences between the cities and communities inhabiting them, the territorial structure and balance between the centre and outskirts, economic development and need for investments, and finally traditions and advancement of urban activism and participation, as well as the varying design of the participatory budgeting itself, especially concerning classification of projects and their encouraged objectives - it would be very difficult to provide an overall classification, especially within the scope of a paper. However, it is possible to attempt consideration of some types of projects which are actually implemented and their potential impact (reserving that this is not an attempt to build an exclusive classification).

\section{- soft projects vs. investment projects}

In general, a trend is visible to balance investments in sub-local infrastructure and community-centred projects with respect to the number of projects. For instance, in the case of Białystok in municipal-level projects, the number of soft and investment projects is equal, while in Katowice $75 \%$ city-level projects were hard ones. On the district level soft projects also made a slight minority (36\% in Białystok and $40 \%$ in Katowice). It should be stressed that especially on the district level these were frequently quite simple initiatives, actually falling into the regular scope of municipal responsibilities, e.g. a road joining 'Słoneczny Stok' neighbourhood with Mruczkowska Street (Białystok, 249,000 PLN), parking spots at 'Wysoki Stoczek' neighbourhood (Białystok, 202,500 PLN), 
the repair of street and pavement surfaces at Wilimowskiego Street (Katowice, 397,500 PLN) or a 'safe and colourful' playground at Zawodzie (Katowice, 300,000 PLN); more innovative initiatives are not so frequent. Soft projects are quite naturally much less expensive, with two outstanding types: support for libraries, especially in Katowice (20 projects concerning purchase of new books, audiobooks and other items for libraries throughout the city and six other projects implemented at and by libraries, funding ranging from 2,500 to 40,000 PLN) and sublocal feasts, e.g. Silesian Feast at Murcki (Katowice, 30,000 PLN) or Family Feast at Piaski (Białystok, 13,900 PLN). Some of the feasts to be funded were organised or co-organised by Roman Catholic parishes (e.g. St. Father Pio Parish Sports and Family Feast, Białystok, 24,900 PLN).

\section{- projects for children/young families}

A large group of projects involve initiatives related to specific needs of young families or families with children, some of which were developed and/or co-organised by schools or kindergartens. This probably results from significant participation from exactly this group of inhabitants: middle class, aged 30 through 45, who either have kids or plan to have them within a few years. Many of those projects involve publicly accessible playgrounds: the playground at Kopiec Piłsudskiego (Kraków, 130,000 PLN), the repair of playground equipment near ul. Krośnieńska and ul. Nowosądecka (Rzeszów, 180,000 PLN). These projects may also involve school/kindergarten play or sports facilities: expansion of a playground built in the gardens of Primary School no. 39 for children aged up to 10 - pupils of the school and kindergarten and other inhabitants of the Dąbie neighbourhood (Kraków, 20,000 PLN) or improving the infrastructure of the kindergarten building and its surroundings (Rzeszów, 180,000 PLN). Some of the projects were also more innovative and original: fourteen district projects focused on first aid training for children (Kraków, 2,600-4,500 PLN). Importantly, there are a few projects concerning activisation of the youngest generation, e.g. football as an alternative to a computer - a series of organised sports training for children and youth (Rzeszów, 49,520 PLN).

In all of the analysed cities there was also funding for social activisation of elderly inhabitants, such as 'The centre for active seniors' (Olsztyn, 300,000 PLN) or 'Nordic walking with babies and seniors' (Gdańsk, 4,875 PLN). Participatory budgeting also provided for funding initiatives for people with disabilities. It can be highlighted that these projects did not directly address the problems of marginalisation.

\section{- sports-related projects and healthy lifestyle projects}

Another important and frequent group of projects involved initiatives related to healthy lifestyle, especially sports. Once again, this is a reflection of the attitudes and expectations of the groups who participate in the processes of 
applications development and in the voting itself. This category frequently includes increasingly popular outdoor fitness equipment, e.g. construction of eight outdoor fitness outlets with light architecture, e.g. benches etc. (Gorzów Wielkopolski, 500,000 PLN). A very popular area of projects submitted and selected concerns cycling. For example, in 2018 two out of four big projects in Opole were related to bicycling (development of bicycling infrastructure in Opole for 499,000 PLN and safe cycling routes in the city centre for 500,000 PLN) and another one oversaw construction of changing rooms at the football pitch of a club (500,000 PLN).

There are also quite a few sport-related soft projects, e.g. district project of a cycle of medium-level sports activities for various age groups (Gorzów Wielkopolski, 5,500 PLN) or football tournaments for children and adults (Opole, 100,000 PLN).

\section{- revitalisation projects}

The final category to be analysed concerns revitalisation projects. From its beginnings, participatory budgeting was designed to boost social inclusion and support the groups which are marginalised or at risk of marginalisation (Shybalkina - Bifulco, 2018), although the impact of such initiatives on redistributive effect has not been clearly evidenced and requires further analysis (Hong - Shine, 2018). Still, among its other objectives, participatory budgeting is supposed to serve to eliminate inequalities inside the city and tensions between the city-centre and outskirts in order to stimulate more sustainable development, so revitalisation initiatives to support marginalised neighbourhoods and communities affected by underinvestment should play an important role. This could be a chance to change the developmental dynamics of those parts of the city. However, none of the analysed major cities in Poland provided for any sort of special attention to such projects within the participatory budgeting processes. In no city was there a separate category for revitalisation projects or extra assistance for initiators of such applications. It does not mean that the city authorities are not concerned about revitalisation. They do not, however, use participatory budgeting as a measure to stimulate it. Initiatives falling in this category can be found among selected projects in Katowice (Revitalisation of the ks. Franciszek Macherski square and maintenance of the Silesian Uprising Fighters statue, 37,000 PLN), in Kraków (Teodor Axentowicz square revitalisation, 72,000 PLN; revitalisation of Słowacki Avenue, 40,000 PLN; revitalisation of historic stadium, 180,000 PLN); in Torun (revitalisation of a square on St. Joseph Street, 120,000 PLN) or in Zielona Góra (historic surrounding of an old overpass), but this is not a major group of projects. This may be due to the fact that inhabitants of districts and neighbourhoods that require revitalisation are not prone to participate and their needs and expectations are not well audible within the participatory budgeting process. This is a well-known problem of 
participatory budgeting in the $21^{\text {st }}$ century, as shown by Celina Su's study of New York participatory budgeting initiative: 'A particular puzzle lies in how and why inclusion does not necessarily lead to redistribution' (Su, 2017, p. 74).

\section{Conclusions}

The analysis of just a single year of participatory budgeting in the eighteen cities which are voivedeship capitals shows the popularity of the process. It is broadly applied, and in some cases quite large amounts are assigned to the process, even though they still account for a small percentage of municipal budgets. This may be a reason why the current participation of the citizens in the project selection state is not always satisfactory, even though local authorities take efforts to make it as available as they can.

It is evident that this tool of encouraging citizen participation is broadly known in Polish local governments, and that practices (concerning the level of funding, forms of counselling, as well as of projects selected) are easily dispersed. This suggests that the legal provisions making introduction of this solution obligatory for some types of local governments are not necessary, since effectiveness of this tool may be enough to promote it and the increasingly influential local movements may press local authorities to apply it.

On the other hand, Polish metropolitan participatory budgeting serves only some objectives typical for this process. It does empower citizens, thus stimulating their participation in city governance, although the turnout at the final votes to select projects for implementation suggests that the initiative still reaches too few citizens to actually change the local and sub-local communities' attitude to the right to and responsibility for their surroundings. This conclusion corresponds also to the findings concerning types of projects selected and implemented, as they involve lifestyle rather than quality of life. Certainly, participatory budgeting in the analysed cities could be applied more effectively in terms of encouraging more equitable and sustainable development. The findings about participatory budgeting in Poland thus also match issues and problems identified by studies in other parts of the world, like Lerner's study on New York participatory budgeting (Lerner 2017).

It seems that introduction of a legal obligation to apply participatory budgeting is not so important in the current Polish situation as establishment of experience sharing and good practice exchange fora to develop and expand participatory budgeting so as to make it a part of broader governance scheme. It is a very popular tool in modern Poland, so it doesn't need promotion, but it needs to be incorporated in a more advanced and complex system of methods to transform modern local communities. 
Table 1: Selected characteristics of Polish voivodeship capitals

\begin{tabular}{|c|c|c|c|c|c|}
\hline voivodeship & city & $\begin{array}{c}\text { registered } \\
\text { population }\end{array}$ & $\begin{array}{c}\text { population } \\
\text { change } \\
\mathbf{2 0 1 5 - 2 0 1 7}\end{array}$ & $\begin{array}{c}\text { unemploy- } \\
\text { ment rate }\end{array}$ & $\begin{array}{c}\text { municipal budget } \\
\text { expenses in 2018 } \\
\text { [PLN] }\end{array}$ \\
\hline Dolny Śląsk & Wroctaw & 638,586 & $+0.44 \%$ & $2.1 \%$ & $4,482,000,000.00$ \\
\hline Kujawsko-Pomorskie & Bydgoszcz & 352,313 & $-0.94 \%$ & $3.9 \%$ & $2,338,640,916.00$ \\
\hline Kujawsko-Pomorskie & Toruń & 202,562 & $-0.06 \%$ & $5.2 \%$ & $1,253,400,000.00$ \\
\hline Lubelskie & Lublin & 339,85 & $-0.26 \%$ & $6.2 \%$ & $2,280,735,363.32$ \\
\hline Lubuskie & Gorzów & 124,295 & $+0.43 \%$ & $2.7 \%$ & $860,295,543.00$ \\
\hline Lubuskopolski & Zielona Góra & 139,819 & $+0.80 \%$ & $3.4 \%$ & $1,098,429,533.00$ \\
\hline tódzkie & tódź & 690,422 & $-1.51 \%$ & $6.3 \%$ & $4,071,559,916.00$ \\
\hline Małopolska & Kraków & 767,348 & $+0.83 \%$ & $2.7 \%$ & $5,581,357,284.00$ \\
\hline Mazowsze & Warszawa & $1,764,615$ & $+1.2 \%$ & $2.0 \%$ & $17,671,266,007.00$ \\
\hline Opolskie & Opole & 128,14 & $+7.74 \% *$ & $3.9 \%$ & $1,124,494,608.00$ \\
\hline Podkarpacie & Rzeszów & 189,662 & $+2.03 \%$ & $5.4 \%$ & $1,471,906,955.00$ \\
\hline Podlasie & Biatystok & 297,288 & $+0.44 \%$ & $7.0 \%$ & $2,354,943,160.00$ \\
\hline Pomorskie & Gdańsk & 582,205 & $+2.69 \%$ & $2.7 \%$ & $3,354,000,000.00$ \\
\hline Śląsk & Katowice & 296,292 & $-1.21 \%$ & $2.2 \%$ & $2,345,802,549.00$ \\
\hline Świętokrzyskie & Kielce & 196,804 & $-0.63 \%$ & $5.8 \%$ & $1,407,675,939.00$ \\
\hline Warmińsko-Mazurskie & Olsztyn & 173,07 & $-0.22 \%$ & $4.5 \%$ & $1,253,400,000.00$ \\
\hline Wielkopolska & Poznań & 538,633 & $-0.68 \%$ & $1.4 \%$ & $3,982,779,681.00$ \\
\hline Szczecin & 405,657 & $-0.44 \%$ & $3.1 \%$ & $2,854,000,000.00$ \\
\hline
\end{tabular}

Source: Statistics Poland data for 2017, municipal budgets for 2018 published at the municipalities' websites (the large increase of the population in Opole resulted from the change of the city borders by inclusion some villages formerly belonging to neighbouring communities) 
Table 2: Voter turnout in local elections in $\mathbf{2 0 1 8}$

\begin{tabular}{|c|c|c|c|}
\hline \multicolumn{2}{|c|}{ voivodeship } & \multicolumn{2}{|c|}{ city } \\
\hline Dolny Śląsk & $46.50 \%$ & Wroctaw & $52.04 \%$ \\
\hline Kujawsko-Pomorskie & \multirow{2}{*}{$46.25 \%$} & Bydgoszcz & $52.56 \%$ \\
\hline Kujawsko-Pomorskie & & Toruń & $52.61 \%$ \\
\hline Lubelskie & $51.62 \%$ & Lublin & $50.96 \%$ \\
\hline Lubuskie & \multirow{2}{*}{$45.54 \%$} & Gorzów Wielkopolski & $53.49 \%$ \\
\hline Lubuskie & & Zielona Góra & $46.35 \%$ \\
\hline Łódzkie & $49.31 \%$ & Łódź & $57.29 \%$ \\
\hline Małopolska & $52.20 \%$ & Kraków & $55.26 \%$ \\
\hline Mazowsze & $61.52 \%$ & Warszawa & $66.9 \%$ \\
\hline Opolskie & $45.36 \%$ & Opole & $54.85 \%$ \\
\hline Podkarpacie & $49.56 \%$ & Rzeszów & $54.06 \%$ \\
\hline Podlasie & $47.23 \%$ & Białystok & $51.97 \%$ \\
\hline Pomorskie & $52.75 \%$ & Gdańsk & $57.70 \%$ \\
\hline Śląsk & $44.47 \%$ & Katowice & $51.55 \%$ \\
\hline Świętokrzyskie & $51.57 \%$ & Kielce & $52.33 \%$ \\
\hline Warmińsko-Mazurskie & $46.40 \%$ & Olsztyn & $49.23 \%$ \\
\hline Wielkopolska & $47.67 \%$ & Poznań & $54.43 \%$ \\
\hline Zachodniopomorskie & $45.14 \%$ & Szczecin & $43.15 \%$ \\
\hline
\end{tabular}


Table 3: Amounts assigned to participatory budgeting (absolute numbers and percentage of the city's budget)

\begin{tabular}{|c|c|c|c|}
\hline voivodeship & city & [PLN] & $\begin{array}{l}\text { percentage of the } \\
\text { municipal budget }\end{array}$ \\
\hline Dolny Śląsk & Wroctaw & $25,250,000$ & $0.56 \%$ \\
\hline Kujawsko-Pomorskie & Bydgoszcz & $13,300,000$ & $0.57 \%$ \\
\hline Kujawsko-Pomorskie & Toruń & $7,070,000$ & $0.56 \%$ \\
\hline Lubelskie & Lublin & $15,000,000$ & $0.66 \%$ \\
\hline Lubuskie & Gorzów Wielkopolski & $6,180,000$ & $0.72 \%$ \\
\hline Lubuskie & Zielona Góra & $6,000,000$ & $0.55 \%$ \\
\hline Łódzkie & Łódź & $40,000,000$ & $0.98 \%$ \\
\hline Małopolska & Kraków & $14,450,000$ & $0.26 \%$ \\
\hline Mazowsze & Warszawa & $64,000,000$ & $0.36 \%$ \\
\hline Opolskie & Opole & $2,500,000$ & $0.22 \%$ \\
\hline Podkarpacie & Rzeszów & $5,500,000$ & $0.37 \%$ \\
\hline Podlasie & Biatystok & $10,000,000$ & $0.42 \%$ \\
\hline Pomorskie & Gdańsk & $14,000,000$ & $0.42 \%$ \\
\hline Śląsk & Katowice & $22,800,000$ & $0.97 \%$ \\
\hline Świętokrzyskie & Kielce & $5,000,000$ & $0,36 \%$ \\
\hline Warmińsko-Mazurskie & Olsztyn & $3,730,000$ & $0,30 \%$ \\
\hline Wielkopolska & Poznań & $20,000,000$ & $0,50 \%$ \\
\hline Zachodniopomorskie & Szczecin & $8,000,000$ & $0.28 \%$ \\
\hline
\end{tabular}


Table 4: Number of projects chosen for implementation and average value.

\begin{tabular}{|c|c|c|c|}
\hline voivodeship & city & number & value \\
\hline Dolny Śląsk & Wroctaw & 63 & $400,793.65$ \\
\hline Kujawsko-Pomorskie & Bydgoszcz & 49 & $271,428.57$ \\
\hline Kujawsko-Pomorskie & Toruń & 67 & $105,522.39$ \\
\hline Lubelskie & Lublin & 44 & $340,909.09$ \\
\hline Lubuskie & Gorzów Wielkopolski & 36 & $171,666.67$ \\
\hline Lubuskie & Zielona Góra & 24 & $250,000.00$ \\
\hline Łódzkie & Łódź & 228 & $175,438.60$ \\
\hline Małopolska & Kraków & 120 & $120,458.33$ \\
\hline Mazowsze & Warszawa & 850 & $75,294.12$ \\
\hline Opolskie & Opole & 18 & $138,888.89$ \\
\hline Podkarpacie & Rzeszów & 36 & $152,777.78$ \\
\hline Podlasie & Białystok & 36 & $277,777.78$ \\
\hline Pomorskie & Gdańsk & 106 & $132,075.47$ \\
\hline Śląsk & Katowice & 126 & $180,952.38$ \\
\hline Świętokrzyskie & Kielce & 12 & $416,666,67$ \\
\hline Warmińsko-Mazurskie & Olsztyn & 28 & $155,416.67$ \\
\hline Wielkopolska & Poznań & 30 & $666,666.67$ \\
\hline Zachodniopomorskie & Szczecin & 13 & $615,384.62$ \\
\hline
\end{tabular}


Table 5: Division of participatory budgeting into different categories.

\begin{tabular}{|c|c|c|}
\hline voivodeship & city & \\
\hline Dolny Śląsk & Wroctaw & $\begin{array}{l}4 \text { municipal-level projects, } 57 \text { district projects, } 2 \\
\text { projects related to historic monuments }\end{array}$ \\
\hline Kujawsko-Pomorskie & Bydgoszcz & $\begin{array}{l}\text { municipal-level projects for the first time and } 10 \\
\text { million PLN for each neighbourhood }\end{array}$ \\
\hline Kujawsko-Pomorskie & Toruń & $\begin{array}{l}\text { 30\% for municipal-level projects and } 70 \% \text { for } \\
\text { sublocal-level projects }\end{array}$ \\
\hline Lubelskie & Lublin & $\begin{array}{l}5 \text { big projects and } 39 \text { small projects ( } 15 \text { projects } \\
\text { within amounts guaranteed for quarters of the city) }\end{array}$ \\
\hline Lubuskie & Gorzów Wielkopolski & $\begin{array}{c}2 \text { municipal-level projects (one soft and one } \\
\text { investment), } 29 \text { district projects and } 5 \text { educational } \\
\text { projects }\end{array}$ \\
\hline Lubuskie & Zielona Góra & $\begin{array}{l}\text { municipal projects ( } 2 \text { of them) and projects } \\
\text { submitted for } 5 \text { districts within the city ( } 4 \text { per district) }\end{array}$ \\
\hline Łódzkie & Łódź & $\begin{array}{l}204 \text { district-level projects (mean value 147,107.84 PLN) } \\
\text { and } 24 \text { municipal-level projects (mean value 460,250 } \\
\text { PLN) }\end{array}$ \\
\hline Matopolska & Kraków & $\begin{array}{l}8,000,100 \text { for municipal-level projects and } 4,454,900 \\
\text { PLN for quarter-level projects }\end{array}$ \\
\hline Mazowsze & Warszawa & $\begin{array}{l}\text { participatory budgeting organised on the level of } \\
\text { quarters (eighteen of them), subdivided into districts }\end{array}$ \\
\hline Opolskie & Opole & 4 big projects, 4 small projects and 10 micro-projects \\
\hline Podkarpacie & Rzeszów & $\begin{array}{l}\text { 1st category for municipal-level investments } \\
(4,000,000 \text { PLN); } 2 \text { nd category for neighbourhood- } \\
\text { level investments ( } 2,900,000 \text { PLN) and 3rd category } \\
\text { for soft projects ( } 600,000 \text { PLN) }\end{array}$ \\
\hline Podlasie & Białystok & 11 municipal-level projects and 25 projects in districts \\
\hline Pomorskie & Gdańsk & $\begin{array}{l}5 \text { municipal-level projects (mean value of } 609,228.40 \\
\text { PLN) and projects for } 24 \text { neighbourhood projects }\end{array}$ \\
\hline Śląsk & Katowice & $\begin{array}{c}\text { municipal level ( } 12 \text { - mean value of } 250,066.67 \text { PLN) } \\
\text { and quarters (114) projects }\end{array}$ \\
\hline Świętokrzyskie & Kielce & $\begin{array}{l}2 \text { big projects }(1,800,000 \text { ad } 2,500,000 \text { PLN), } 10 \text { small } \\
\text { projects ( } 150,000 \text { PLN each) }\end{array}$ \\
\hline Warmińsko-Mazurskie & Olsztyn & $\begin{array}{l}24 \text { neighbourhood level projects (mean value } \\
\text { 105,416.67) and } 4 \text { municipal level (integrated) projects } \\
\text { (mean value 300,000) }\end{array}$ \\
\hline Wielkopolska & Poznań & $\begin{array}{c}\text { municipal level (6,000,000 PLN and } 3 \text { projects), } \\
\text { district level (14,000,000 PLN for } 13 \text { districts and } 27 \\
\text { projects) }\end{array}$ \\
\hline Zachodniopomorskie & Szczecin & $\begin{array}{c}\text { municipal projects (1), } 4 \text { districts divided into small } \\
\text { and big projects ( } 1 \text { or } 2 \text { projects in each of the } 8 \\
\text { categories) }\end{array}$ \\
\hline
\end{tabular}


Table 6. Participation in the consultation voting stage of participatory budgeting.

\begin{tabular}{|c|c|c|c|c|}
\hline voivodeship & city & voting methods & $\begin{array}{l}\text { number of } \\
\text { voters }\end{array}$ & $\begin{array}{l}\text { percentage of } \\
\text { city inhabitants }\end{array}$ \\
\hline Dolny Śląsk & Wroctaw & online or paper vote & 68,67 & $10.77 \%$ \\
\hline Kujawsko-Pomorskie & Bydgoszcz & online or paper vote & 55,218 & $15,44 \%$ \\
\hline Kujawsko-Pomorskie & Toruń & online or paper vote & 12,72 & $6.28 \%$ \\
\hline Lubelskie & Lublin & online or paper vote & 25,318 & $7.44 \%$ \\
\hline Lubuskie & $\begin{array}{c}\text { Gorzów } \\
\text { Wielkopolski }\end{array}$ & $\begin{array}{l}\text { meetings, online or paper } \\
\text { vote }\end{array}$ & 10,437 & $8.42 \%$ \\
\hline Lubuskie & Zielona Góra & online or paper vote & 36,593 & $26.17 \%$ \\
\hline Łódzkie & Łódź & online or paper vote & 97,974 & $14.07 \%$ \\
\hline Małopolska & Kraków & online vote & 32,958 & $4.30 \%$ \\
\hline Mazowsze & Warszawa & online or paper vote & 89,807 & $5,12 \%$ \\
\hline Opolskie & Opole & online or paper vote & 8,948 & $7.54 \%$ \\
\hline Podkarpacie & Rzeszów & online or paper vote & 19,712 & $10.39 \%$ \\
\hline Podlasie & Biatystok & online or paper vote & 23,134 & $7.78 \%$ \\
\hline Pomorskie & Gdańsk & exclusively online vote & 44,655 & $9.68 \%$ \\
\hline Śląsk & Katowice & $\begin{array}{l}\text { exclusively online vote } \\
\text { (stationary outlets for } \\
\text { people who find online } \\
\text { vote too difficult) }\end{array}$ & 46,889 & $15.73 \%$ \\
\hline Świętokrzyskie & Kielce & $\begin{array}{l}\text { online, paper vote or in } \\
\text { person }\end{array}$ & 44,114 & $22.42 \%$ \\
\hline Warmińsko-Mazurskie & Olsztyn & online or paper vote & 41,246 & $23.84 \%$ \\
\hline Wielkopolska & Poznań & online vote & 55,631 & $10.29 \%$ \\
\hline Zachodniopomorskie & Szczecin & online or paper vote & 26,378 & $6.50 \%$ \\
\hline
\end{tabular}




\section{References}

Act of $8^{\text {th }}$ March 1990, on Communal Self-Government, Journal of Laws of 1990 No. 16, item 95, as amended, art. $5 \mathrm{a}$, item 5 .

Act of $5^{\text {th }}$ June 1998 on Poviat Self-Government, Journal of Laws of 1998 No. 91, item 578, as amended, chapter 9.

Act of $11^{\text {th }}$ April 2001, on amendment of the acts on the commune government, poviat government, voivodeship self-government and government administration in voivodeship, along with some other acts, Journal of Laws of 2001 No. 45, item 497.

Avritzer, Leonardo (2017): Participation in democratic Brazil: from popular hegemony and innovation to middle-class protest, Opinião Pública, Campinas 23 (1).

Brun-Martos, Maria Isabel - Lapsley, Irvine (2017): Democracy, governmentality and transparency: participatory budgeting in action, Public Management Review 19 (7).

Charter of Fundamental Rights of the European Union (2000/C 364/01).

Chrzanowski, Mateusz - Sobczak, Jacek (2017): Samorządy w procesie decentralizacji władzy publicznej. Self-governments in the process of decentralisation of public authority, Stowarzyszenie Naukowe Pro Scientia luridica.

De Olivero Dutra, Olivio (2014): Preface, [in:] Hope for Democracy. 25 Years of Participatory Budgeting Worldwide.

Demediuk, Peter - Solli, Rolf - Adolfsson, Petra (2012): People Plan their Park: Voice and Choice through Participatory Budgeting, The International Journal of Interdisciplinary Social Sciences 6 (5): 185-198.

European Charter of Local Self-Government (1985), https://rm.coe.int/168007a088, accessed on 18-2-2019.

Hartog Martijn - Bakker Kevin (2018): Participatory Budgeting in Public Administrations: Barriers and Opportunities for a Transparent Government, Conference: European Conference on Digital Government (ECDG).

Hildreth R. W. - Miller Steven A. (2018): From Projects to Problems: A Deweyan Analysis of Participatory Budgeting, Journal of Social Philosophy 49 (2): Summer 2018, pp 252-269.

Hong, Sounman - Shine Cho, B. (2018): Citizen participation and the redistribution of public goods, Public Administration, 2018; 96: 481-496.

International Fund for Agricultural Development (1999), Good Governance: an Overview.

Kębłowski, Wojciech (2014): Budżet partycypacyjny. Ewaluacja, Instytut Obywatelski.

Kmieciak, Robert (editor) (2016): Decentralizacja jako fundament demokracji obywatelskiej, Wydawnictwo Naukowe WNPiD UAM.

Kobielska, Katarzyna - Lisowska, Alicja (2014): Dobre rządzenie w matych gminach. Empiryczny wymiar nowego paradygmatu rozwoju.

Lerner, Josh (2017): Conclusion: Time for Participatory Budgeting to Grow Up, New Political Science 39 (1): 156-160. 
Liebmann, George W. (2000): Solving Problems Without Large Government. Devolution, Fairness and Equality, Praeger.

Mikrogranty, https://www.wroclaw.pl/mikrogranty/, accessed on the 11-3-2019.

Ministry of Internal Affairs and Administration, http://administracja.mswia.gov.pl/adm/baza-jst/843,Samorzad-terytorialny-w-Polsce.html, accessed on the 11-3-2019.

Mueller, Sean (2015): Theorising Decentralisation. Comparative Evidence from Sub-national Switzerland, ECPR Press.

National Electoral Commission, https://pkw.gov.pl/352_Kadencja_2014-2018, accessed on the 11-3-2019.

Official Portal of the Municipality of Gdansk, https://www.gdansk.pl/panel-obywatelski, accessed on the 24-1-2019.

Olejniczak, Jarosław - Bednarska-Olejniczak, Dorota (2008): Participatory Budgeting in Poland in 2013-2018 - Six Years of Experiences and Directions of Changes, Dias, Nelson, ed., Hope for Democracy. 30 Years of Participatory Budgeting Worldwide, Epopeia Records | Oficina.

Rytel-Warzocha Anna (2018): The Role and Impact of Participatory Instruments in Poland. Dusk or Dawn of Direct Democracy?, 5th International Multidisciplinary Scientific Conference on Social Sciences \& Arts SGEM.

Shybalkina, luliia - Bifulco, Robert (2018): Does Participatory Budgeting Change the Share of Public Funding to Low Income Neighborhoods?, Public Budgeting \& Finance (1): 45-66.

Skrzypiński, Dariusz (2017): Transformacja społeczno-gospodarcza polskich województw w warunkach przynależności do Unii Europejskiej, Alberski, R. - Cichosz M., (editors), Gra o regiony 2014. Wybory do sejmików województw, Institute of Political Science, University of Wrocław.

Stowarzyszenie Klon/Jawor (2014): Zaangażowanie społeczne Polek i Polaków. Wolontariat, filantropia, 1\% i wizerunek organizacji pozarządowych. Raport z badania 2013.

Su, Celina (2017): From Porto Alegre to New York City: Participatory Budgeting and Democracy, New Political Science 39 (1): 67-75.

Swaner, Rachel (2017), Trust Matters: Enhancing Government Legitimacy through Participatory Budgeting, New Political Science. 39 (1): 95-108.

Sześcito, Dawid - Kulesza, Michał (2012): Local Government in Poland, Angel-Manuel Moreno, ed., Local Government in the Member States of the European Union: A Comparative Legal Perspective, National Institute of Public Administration, Spain, 485-50.

Tsobanoglou, Gieorgios - Harms, Hans (2018): Citizen's Participation and the Crisis of Representation in Europe. Models of Citizen Participation and the Quest for Local Democracy, Journal of Regional \& Socio-Economic Issues 8 (2): 47-59.

Wójcicki, Michał (2013): Pojęcie, istota i formy partycypacji społecznej w procesie planowania przestrzennego, Rozwój Regionalny i Polityka Regionalna, no. 24.

\section{Website sources of data}

Biatystok: https://www.bialystok.pl/pl/dla_mieszkancow/bialystok_obywatelski/budzet_obywatelski/ 
Bydgoszcz: https://www.bdgbo.pl/

Gdańsk: https://www.gdansk.pl/budzet-obywatelski

Gorzów Wielkopolski: http://www.gorzow.pl/PL/3452/Budzet_obywatelski_2019/

Katowice: http://bo.katowice.eu/Strony/default.aspx

Kielce: https://budzetobywatelski.kielce.eu/

Kraków: https://budzet.krakow.pl/

Lublin: https://obywatelski.lublin.eu/

Łódź: https://uml.lodz.pl/dla-mieszkancow/lodzianie-decyduja/budzet-obywatelski/

Olsztyn: http://www.obo.olsztyn.eu/

Opole: https://www.opole.pl/budzet-obywatelski-opola-glosowanie/

Poznań: https://budzet.um.poznan.pl/pbo2019/

Rzeszów: http://rbo.rzeszow.pl/

Szczecin: https://sbo.szczecin.eu/

Toruń: https://www.torun.pl/pl/miasto/budzet-partycypacyjny-torunia-2018

Warszawa: http://twojbudzet.um.warszawa.pl/

Wrocław: https://www.wroclaw.pl/rozmawia/wroclawski-budzet-obywatelski

Zielona Góra: http://www.zielona-gora.pl/PL/971/6524/Budzet_obywatelski_2018_-_glosowanie/

Malgorzata Madej is the Assistant Professor at the Institute of Political Science, University of Wrockaw, Poland. ORCID: 0000-0002-5274-8614. E-mail: malgorzata. madej@uwr.edu.pl 